\title{
Clinical, parasitological, and serological characteristics of toxoplasmosis in felines (Felis catus) infected with isolates i and III of Toxoplasma gondii
}

\section{Característica clínica, parasitológica e sorológica da toxoplasmose em felinos (Felis catus) infectados com os isolados I e III de Toxoplasma gondii}

\author{
Weslen Fabricio Pires Teixeira ${ }^{1 *}$; Dielson da Silva Vieira ${ }^{2}$; Welber Daniel Zanetti \\ Lopes $^{1}$; Gustavo Felippelli ${ }^{3}$; Regina Maura Bueno Franco ${ }^{4}$; Nilson Branco ${ }^{4}$; Vando \\ Edésio Soares $^{5}$; Katia Denise Saraiva Bresciani ${ }^{6}$; Alvimar José da Costa ${ }^{7}$
}

\begin{abstract}
Toxoplasmosis is a parasitic disease caused by the protozoan Toxoplasma gondii, characterized by a clinical or subclinical infection attributed mainly to the isolate of the parasite responsible for the infection. Although domestic felines are considered the only urban hosts of this parasite and, consequently, the animals responsible for perpetuating $T$. gondii cycle in this environment, there is still a lack of information regarding the potential of different strains/isolates of this parasite and appearance of clinical signs during infection in domestic felines. In this context, the objective of the present study was to evaluate the clinical, parasitological, and serological characteristics of toxoplasmosis in felines infected with $T$. gondii isolates type I (RH strain) and III (P strain). Twelve healthy and serologically negative felines were selected for $T$. gondii (IgG titer $<16$ ). These animals were divided into three experimental groups, GI: (P1, P2, P3, and P4) inoculated with 600 cysts of T. gondii (P strain), GII: (RH1, RH2, RH3, and RH4) inoculated with $2 \times 10^{5}$ tachyzoites (RH strain), and GIII: (C1, C2, C3, and $\mathrm{C} 4$ ) uninoculated. From the seventh day before (day -7$)$ to the 70th day after inoculation (DAI), the animals were observed daily to verify the occurrence of alterations in the digestive, nervous, locomotor, cardiorespiratory, and urinary systems, as well as skin and appendages. The clinical signs most observed in felines inoculated with $T$. gondii were apathy, hyporexia, shivering, nasal secretion, ocular secretion, and diarrhea. The results obtained in this study allow inferring that $T$. gondii isolate type I (RH strain) was more pathogenic to feline species than isolate type III (P strain), although both showed clinical symptomatology in all infected animals.
\end{abstract}

Key words: Toxoplasmosis. Parasites. Experimental infection. Oocysts.

\footnotetext{
Profs., Pesquisadores, Programa de Pós-Graduação em Ciência Animal, Universidade Federal de Goiás, UFG, Goiânia, GO, Brasil. E-mail: weslenteixeira@hotmail.com; wdzlopes@hotmail.com

2 Discente, Programa de Pós-Graduação em Ciência Animal, Faculdade de Medicina Veterinária, Universidade Estadual Paulista "Júlio de Mesquita Filho", FMVA/UNESP, Araçatuba, SP, Brasil. E-mail: dielsonveterinario@gmail.com

3 Prof. Dr., Centro Universitário de Rio Preto, UNIRP, São José do Rio Preto, SP, Brasil. E-mail: gusvetfelippelli@gmail.com

4 Profs. Pesquisadores, Universidade Estadual de Campinas, UNICAMP, Campinas, SP, Brasil. E-mail: mfranco@unicamp.br; branco@unicamp.br

5 Prof. Dr., Universidade Camilo Castelo Branco, UNICASTELO, Descalvado, SP, Brasil. E-mail: soaresvando@gmail.com

${ }^{6}$ Profa Dra., Programa de Pós-Graduação em Ciência Animal, Departamento de Produção e Saúde Animal, FMVA/UNESP, Araçatuba, SP, Brasil.

7 Prof. Dr., Departamento de Patologia Veterinária, FCAV/UNESP, Jaboticabal, SP, Brasil. E-mail: cppar@asbyte.com.br

* Author for correspondence
} 


\section{Resumo}

A toxoplasmose é uma enfermidade parasitária provocada pelo protozoário Toxoplasma gondii, caracterizada por uma infecção de caráter clínica ou subclínica atribuída principalmente ao isolado do parasito responsável pela infecção. Apesar dos felinos domésticos serem considerados os únicos hospedeiros urbanos desse parasito, e consequentemente, os animais responsáveis pela perpetuação do ciclo do $T$. gondii nesse ambiente, ainda existe uma carência de informações referentes ao potencial de diferentes cepas/isolados do parasito, em provocar o surgimento de sinais clínicos durante a infecção em gatos domésticos. Nesse contexto, o objetivo do presente estudo foi avaliar a característica clínica, parasitológica e sorológica da toxoplasmose em felinos infectados com os isolados tipo I (cepa "RH") e III (cepa "P") de T. gondii. Para tanto, foram selecionados doze felinos saudáveis e sorologicamente negativos para $T$. gondii (título $\operatorname{IgG}<16$ ). Estes animais foram distribuídos em três grupos experimentais, GI: (P1, P2, P3 e P4) inoculados com 600 cistos de T. gondii (cepa "P"), GII: (RH1, RH2, RH3 e RH4) inoculados com $2 \times 10^{5}$ taquizoítos (cepa "RH”) e GIII: (C1, C2, C3 e C4) não inoculados. Do sétimo dia antes (D -7) ao $70^{\circ}$ dia após inoculação (DPI), estes animais foram diariamente observados visando constatar a ocorrência de alterações no sistema digestório, nervoso, locomotor, cardiorrespiratório, urinário, além de pele e anexos. Os sinais clínicos mais observados nos felinos inoculados com $T$. gondii foram: apatia, hiporexia, pelos arrepiados, secreção nasal, secreção ocular e diarreia. Os resultados obtidos neste estudo permitem inferir que o isolado tipo I (cepa RH) de $T$. gondii se mostrou mais patogênico a espécie felina que o isolado tipo III (cepa P), embora ambas tenham provocado sintomatologia clínica em todos os animais infectados.

Palavras-chave: Toxoplasmose. Parasitos. Infecção experimental. Oocistos.

\section{Introduction}

Toxoplasma gondii is an obligatory intracellular protozoan parasite first described in 1908 by Nicolle and Manceaux, responsible for a disease known as toxoplasmosis (FERGUSON, 2009). The clinical symptoms of feline toxoplasmosis are diverse, showing clinical signs such as fever, ocular inflammation, anorexia, lethargy, respiratory disease, weight loss, and neurological abnormalities (LAPPIN et al., 1989a; DUBEY; CARPENTER, 1993; DUBEY; LAPPIN, 2006; SAKAMOTO et al., 2009). Most of these clinical signs are observed during the acute disease stage, which is characterized by the presence of parasitic tachyzoites in the circulatory system of infected individuals (REY, 2002).

In the chronic stage of infection, tissue cysts of the parasite (DUBEY et al., 1970) are diagnosed and may remain dormant for years in immunocompetent hosts causing no inflammatory reaction (DUBEY et al., 1998). In general, the appearance of clinical symptoms at this disease stage is usually attributed to a host immune deficiency, being type and magnitude of clinical symptomatology evidenced depending on the location of the parasite and degree of tissue injury caused by it (CORREA $\hat{E}$;ORREA, 1992; DUBEY; LAPPIN, 2006). A process known as a toxoplasmic infection can be developed under immunodeficiency conditions, when the rupture of latent tissue cysts happens, followed by the transformation of bradyzoites into tachyzoites, which will again cause parasitemia to migrate to other tissues and may lead to new manifestations clinical trials (BERNSTEEN et al., 1999; LAPPIN, 1999; DUBEY, 2006).

Besides the location of $T$. gondii in the host organism, it is known that the occurrence of clinical signs of toxoplasmosis is directly related to the infecting dose and pathogenicity of the parasite isolate involved in the infection. T. gondii presents three different strains (I, II, and III), each of them classified according to their virulence. The RH (SABIN, 1941) and P strains are classified, respectively, as type I and III isolates of $T$. gondii. Strains belonging to isolate I are considered to be more acute, leading to a higher replication of tachyzoites (PENA et al., 2008). On the other hand, strains of isolate III are more chronic, with a high cistogenic power (SULLIVAN; JEFFERS, 2012). 
There is still a lack of information regarding possible differences between strains/isolates of $T$. gondii in felines regarding the potential to cause the appearance of clinical signs during infection. In this context, the present study aimed to compare the occurrence of clinical signs in experimentally infected felines with type I (RH strain) and III (P strain) isolates of $T$. gondii.

\section{Material and Methods}

\section{Approval in the Ethics Committee on Animal Use}

The experimental protocol of this study was previously submitted and approved by the Ethics Committee on Animal Use (CEUA/FCAV/UNESP

- Campus of Jaboticabal, SP), under the protocol number 024137/13.

\section{Selection of felines}

Twelve male (adult) felines (one to four years old), healthy, and undefined from the municipality of Jaboticabal, SP, kindly provided by their respective tutors, were selected for the accomplishment of this study. The indirect immunofluorescence (IIF) technique (CAMARGO, 1964) was used to select only serologically negative felines for antibodies (IgG) anti-T. gondii (IgG titre < 16).

Management of animals in the pre-inoculation period

After selecting the animals, each feline was maintained separately in duly numbered metal cages equipped with feeding and drinking troughs, platform for rest, box with artificial sand (hygienic wood pellets), and toys. All selected felines were treated with praziquantel $(20 \mathrm{mg})$ and pyrantel pamoate $(230$ $\mathrm{mg}$ ) (Drontal ${ }^{\circledR}$ Cats, Bayer) and vaccinated against rabies (Nobivac ${ }^{\circledR}$ Rabies, MSD Animal Health), chlamydiosis, rhinotracheitis, panleukopenia, and caliciviruses (Felocell ${ }^{\circledR}$ CVR, Zoetis) before starting the study. An acclimatization period (30 days) was established for housing and nutrition conditions (commercial ration and drinking water provided ad libitum) and proposed management.

Distribution of felines in experimental groups and inoculation with T. gondii isolates

The 12 selected felines were distributed by lot into three groups (GI, GII, and GIII) at seven days before inoculation (day-7), as described in Table 1.

Table 1. Distribution of experimental groups, $T$. gondii inoculum used and feline inoculation route.

\begin{tabular}{|c|c|c|c|c|c|}
\hline $\begin{array}{c}\text { Experimental } \\
\text { Groups }\end{array}$ & $\begin{array}{c}\mathrm{N}^{0} \text { of cats per } \\
\text { group }\end{array}$ & $\begin{array}{c}\text { Identification of } \\
\text { felines }\end{array}$ & $\begin{array}{l}\text { Serological } \\
\text { Result }^{*}\end{array}$ & $\begin{array}{l}\text { Inoculum } \\
\text { Dose }\end{array}$ & $\begin{array}{l}\text { Inoculation } \\
\text { Route }\end{array}$ \\
\hline I & 4 & $\begin{array}{l}\text { P1 } \\
\text { P2 } \\
\text { P3 } \\
\text { P4 }\end{array}$ & Negatives $^{* *}$ & 600 cysts & Oral \\
\hline II & 4 & $\begin{array}{l}\text { RH1 } \\
\text { RH2 } \\
\text { RH3 } \\
\text { RH4 }\end{array}$ & Negatives $^{* *}$ & $\begin{array}{c}2 \times 10^{5} \text { tachy- } \\
\text { zoites }\end{array}$ & Subcutaneous \\
\hline III & 4 & $\begin{array}{l}\mathrm{C} 1 \\
\mathrm{C} 2 \\
\mathrm{C} 3 \\
\mathrm{C} 4\end{array}$ & Negatives $^{* *}$ & ND & ND \\
\hline
\end{tabular}

*: indirect immunofluorescence (CAMARGO, 1964) for $T$. gondii. **: IgG titer <16. ND: Not determined. 
The P (isolate type III) and $\mathrm{RH}$ (isolate type I) strains were maintained in mice at the Animal Health Research Center (CPPAR/FCAV/UNESPJaboticabal, SP).

Ten Swiss albino mice with an average age of 35 days were used to obtain $T$. gondii cysts ( $\mathrm{P}$ strain). For this, these rodents were previously inoculated intraperitoneally with approximately ten cysts extracted from a brain of another chronically infected rodent, being observed daily up to the 42nd day after inoculation (DAI). After this period, all of them were euthanized by cervical dislocation (BRASIL, 2013). Each brain was removed using forceps and scissors and transferred to a sterile Falcon tube $(15 \mathrm{~mL})$ together with approximately $1 \mathrm{~mL}$ of physiological solution, where they were macerated using a glass stick. An aliquot of $50 \mu \mathrm{L}$ was taken from the resulting solution, being examined using an optical microscope (40X magnification) for identification and total quantification of $T$. gondii cysts present on each slide.

The standardization of each inoculum containing tissue cysts of the parasite was performed by diluting the previous solution in sterile physiological solution, thus adjusting the number of parasite forms administered in each feline. Ten Swiss albino mice (Mus musculus) that received intraperitoneally tachyzoites of $T$. gondii (RH strain) were used to obtain the inoculum containing tachyzoites of $T$. gondii (RH strain). These mice were euthanized (BRASIL, 2013) at two days after inoculation (+/- 48 hours), being performed the intraperitoneal lavage with $3 \mathrm{~mL}$ of sterile saline solution followed by aspiration of the exudate containing tachyzoites.

The lavages were examined under light microscopy (40X magnification), aiming at verifying the absence of bacteria and blood cells of rodents, and tachyzoites were then quantified on a Neubauer chamber. The procedure to obtain and quantify tachyzoites, as well as the adjustment of the amount of these parasitic forms in physiological solution (standardization of inocula), were carried out on the day of feline inoculation, according to the methodology described by Costa et al. (1977).

Animals belonging to GI received orally on the day zero (D0) 600 cysts (P strain, isolate type III) of $T$. gondii diluted in a physiological solution. This inoculum was administered using a probe coupled to a $10-\mathrm{mL}$ syringe, according to the methodology described by Costa et al. (1977). At the same time, GII felines were inoculated subcutaneously (dorsal region) with $2 \times 10^{5}$ tachyzoites of $T$. gondii $(\mathrm{RH}$ strain, isolate type I) using a $1-\mathrm{mL}$ syringe and needle $(0.80 \times 30 \mathrm{~mm})$ after previous local disinfection with iodized alcohol $(0.1 \%)$. Felines belonging to GIII were not inoculated, remaining as control of the study (Table 1).

Clinical evaluations of felines at pre- and postinoculation

All felines (GI, GII, and GIII) were evaluated daily (day -7 to 70 th DAI) regarding the appearance of clinical signs resulting from toxoplasmic infection. For this, these animals were clinically evaluated for possible alterations in the digestive, nervous, locomotor, cardiorespiratory, and urinary systems, as well as skin and appendages, using the methodologies proposed by Feitosa (2008). The infection was characterized as clinical when any clinical signs of toxoplasmic infection were found. In contrast, the infection was characterized as subclinical in the absence of such clinical signs.

\section{Coproparasitological analyses}

Coproparasitological examinations were carried out from the 1 st to the 17 th DAI in felines belonging to GI. The total excreta of felines were collected daily from sandboxes (properly separated from wood pellets), weighed, homogenized, and subjected to the centrifugal-flotation technique in Sheather solution, followed by sporulation of oocysts in $2 \%$ sulfuric acid for ten days (DUBEY et al., 1972). Search and identification of $T$. gondii oocysts were performed 
under light microscopy with a micrometer objective of 400X using morphological criteria (ZAMAN, 1970) and through the bioassay in mice (DUBEY et al., 1972). Oocysts identified in solutions containing two grams of feces from each feline were quantified on a Neubauer chamber (COSTA et al., 1977). The total number of oocysts excreted for each feline at each observational date was obtained by a simple three rule using the number of total oocysts quantified in 2 grams of feces and the weight obtained from the total daily excreta of each feline.

\section{Search of antibodies (IgG) against T. gondii}

Blood samples $(1 \mathrm{~mL})$ were collected by femoral venipuncture from each feline (GI, GII, and GIII), being conditioned in sterile tubes (without anticoagulant) before the inoculation (day -7 and 0 ) and at the 7th, 14th, 21st, 28th, 42nd, 56th, and 70th day after inoculation (DAI). These samples were centrifuged at $1500 \mathrm{rpm}$ for 10 minutes to obtain serum samples to perform IIF (CAMARGO, 1964).

Further serial dilutions were performed following feline seroconversion ( $\mathrm{IgG}$ titer $>64$ ) aiming at the reciprocal serological titer of antibodies ( $\mathrm{IgG})$ anti-T. gondii in each experimental feline.

\section{Determination of parasitemia}

The parasitemia exerted by $T$. gondii was evaluated in the experimental feline before inoculation (day -7 and 0 ) and in the 7 th, 14th, 21st, 28th, 42nd, 56th, and 70th DAI (COSTA et al., 1977). Blood samples $(1 \mathrm{~mL})$ were collected from felines (GI, GII, and GIII) and transferred into Eppendorf tubes $(2 \mathrm{~mL})$ containing anticoagulant (EDTA). Blood samples were centrifuged at 1500 rpm for 10 minutes to obtain the leukocyte layer, which was aspirated with a pipette and point of 200 uL. Subsequently, each leukocyte layer was inoculated intraperitoneally with a syringe and needle in five mice to perform the bioassay.
After inoculation, mice were observed daily for 42 days. Intraperitoneal exudates from rodents that died from the 3 rd to the 10th day after inoculation were collected for the research of tachyzoites using microscopy.

A serological test for T. gondii antibodies (IgG) and a cystic brain cystectomy were carried out in mice that died from the 11 th to the 42 nd day after inoculation, in addition to the intraperitoneal tachyzoite examination. Serum of mice that presented titer equal to or higher than 32 was considered as a positive sample (CAMARGO, 1964).

\section{Statistical analyses}

Comparisons between the means of serological titers obtained from feline experimental groups (GI, GII, and GIII) were carried out by the KruskalWallis test $(95 \%$ confidence). The comparison between the number of days that parasitemia was detected by $T$. gondii in the different experimental groups was performed by the Fisher's exact test (95\% confidence) using the software SAS (2001).

\section{Results}

\section{Clinical signs observed in felines}

Only one feline (P3) presented subclinical infection, showing no clinical sign during the entire observational period (day 0 to 70 th DAI).

All felines inoculated with tachyzoites (RH strain) of $T$. gondii (GII) had apathy and hyporexia at some time after inoculation. Differently, only one feline (P2) inoculated with tissue cysts (P strain) of the parasite (GI) presented apathy after infection (Table 2).

Bristled fur was the second most observed clinical sign in felines belonging to GII (RH1, RH2, and RH3), followed by pasty feces (RH4) and nasal and ocular secretion (RH2) (Table 2). 
Two felines (P2 and P4) inoculated with tissue cyst (GI) also had diarrhea after inoculation. The occurrence of ocular secretion was also observed in this group, diagnosed in a feline (P1) from the 11th to the 14th DAI (Table 2).

Feline RH1 presented a urethral obstruction at the 49th DAI due to feline interstitial cystitis, a clinical condition that evolved at the 52nd DAI to an exacerbation of the toxoplasmic infection, evidenced by an increase in the anti- $T$. gondii $\mathrm{IgG}$ serological titer from 256 to 1024 . The appearance of nerve signs (Table 2), suggestive of the cerebellar lesion (walking in circles and seizures), was observed at that time. This event led to the treatment $(200 \mathrm{mg} / 5 \mathrm{~mL}$ of sulfamethoxazole $+40 \mathrm{mg} / 5 \mathrm{~mL}$ of trimetropine, administered together with liquid feeding through a nasogastric tube every 12 hours) and exclusion of the animal from the study due to ethical and animal welfare issues.
Excretion of T. gondii oocysts by felines

All felines inoculated with $T$. gondii (GI) brain cysts eliminated oocysts at some experimental time, with a pre-patent period of 5 to 13 days after inoculation. Approximately 2,406,210 oocysts were isolated from all felines (GI) during the elimination period. A peak of oocyst excretion was observed at the 9th DAI, being quantified 1,219,700 parasitic forms in the total of feces collected from all animals at that date. Feline P3 showed the highest excretion rate, totaling 1,455,770 oocysts eliminated over the experimental period (Table 3 ). Mice inoculated intraperitoneally with feline fecal samples containing oocysts during the bioassay were positive after six weeks of inoculation, which was proven by their seroconversion (IIF - titer $>32$ ) and/or observations of cerebral cysts (Table 4).

Table 2. Clinical signs and parasitemia observed in the felines belonging to groups I, II and III during the whole experimental period.

\begin{tabular}{|c|c|c|c|c|c|c|c|c|c|}
\hline \multirow[b]{2}{*}{ Felines } & \multirow[b]{2}{*}{ Groups } & \multicolumn{7}{|c|}{ Clinical Signs/Period (in days) post-inoculation } & \multirow{2}{*}{$\begin{array}{c}\text { Parasitemia/ } \\
\text { Post-inocula- } \\
\text { tion }\end{array}$} \\
\hline & & Apathy & Hiporexia & $\begin{array}{l}\text { Pasty } \\
\text { feces }\end{array}$ & $\begin{array}{c}\text { Bristled } \\
\text { fur }\end{array}$ & $\begin{array}{c}\text { Nasal } \\
\text { Secre- } \\
\text { tion }\end{array}$ & $\begin{array}{c}\text { Ocular } \\
\text { Secretion }\end{array}$ & $\begin{array}{c}\text { Nerve } \\
\text { signs }\end{array}$ & \\
\hline $\mathrm{P} 1$ & \multirow{4}{*}{$\begin{array}{c}\text { I } \\
\text { (Infected } \\
\text { "P") }\end{array}$} & - & - & - & - & - & (11 to 14$)$ & - & $(21)$ \\
\hline $\mathrm{P} 2$ & & (9 to 14 ) & - & (8) & - & - & - & - & (14 and 28) \\
\hline P3 & & - & - & - & - & - & - & - & (7) \\
\hline P4 & & - & - & $(7-8)$ & - & - & - & - & (14) \\
\hline RH1 & \multirow{4}{*}{$\begin{array}{c}\text { II } \\
\text { (Infected } \\
\text { "RH") }\end{array}$} & $\begin{array}{l}(4 \text { to } 13) \\
\text { (49 to } 60)\end{array}$ & $\begin{array}{c}(6 \text { to } 9) \\
(49 \text { to } 60)\end{array}$ & - & (44 to 55$)$ & - & - & $(51)$ & (7 and 14) \\
\hline RH2 & & $(5$ to 44$)$ & (4 to 31$)$ & - & (14 to 25$)$ & $(16)$ & (15 to 17$)$ & - & $\begin{array}{c}(7,28 \text { and } \\
42)\end{array}$ \\
\hline RH3 & & (6 to12) & (9 to 10 ) & - & (7 to 17 ) & - & - & - & (7 and 14) \\
\hline RH4 & & (7 to 11 ) & $\begin{array}{l}(8 \text { to } 11) \\
(22 \text { to } 23)\end{array}$ & $\begin{array}{c}(21 \text { to } \\
23)\end{array}$ & - & - & - & - & (21 and 28) \\
\hline $\mathrm{C} 1$ & \multirow{4}{*}{$\begin{array}{c}\text { III } \\
\text { (Control) }\end{array}$} & - & - & - & - & - & - & - & - \\
\hline $\mathrm{C} 2$ & & - & - & - & - & - & - & - & - \\
\hline $\mathrm{C} 3$ & & - & - & - & - & - & - & - & - \\
\hline $\mathrm{C} 4$ & & - & - & - & - & - & - & - & - \\
\hline
\end{tabular}

$(-)$ : Nothing worthy of note. 

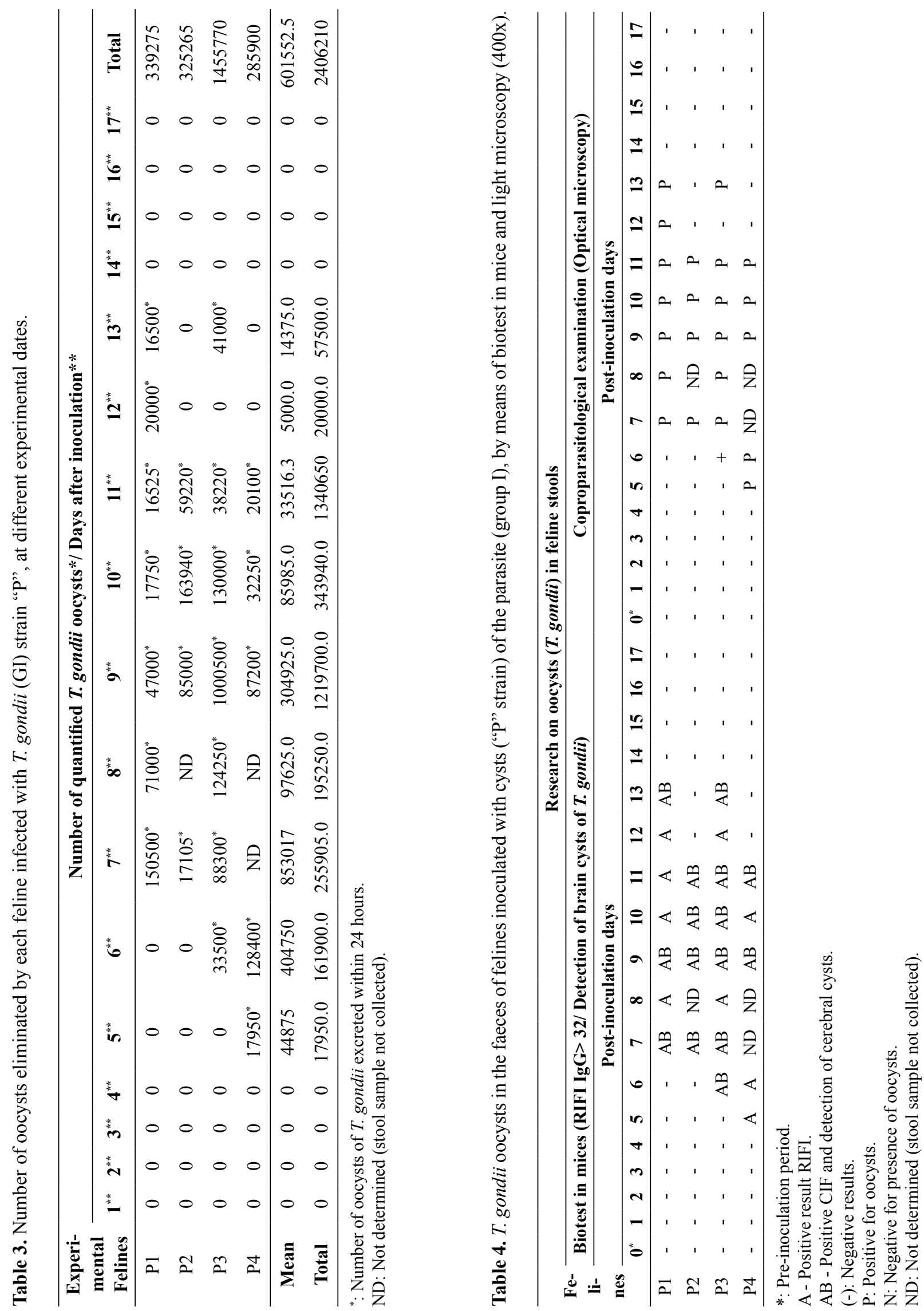


\section{Seroconversion of felines}

Seroconversion was observed only in felines inoculated with $T$. gondii (GI and GII), with titers ranging from 64 to 1024 during the entire experimental period. The mean titer obtained from felines inoculated with tissue cyst (GI) was statistically lower $(\mathrm{p} \leq 0.05)$ when compared to that observed in the group inoculated with tachyzoites (GII) at the 7th, 14th, and 21st DAI, being equivalent in the later dates $(42 \mathrm{nd}, 56 \mathrm{th}$, and 70 th DAI) (Table 5).

Table 5. IgG titers against $T$. gondii and comparisons between titers obtained by means of the indirect immunofluorescence (RIFI) reaction in serological samples collected from cats infected with T. gondii (GI and GII) and uninfected (GIII) at the different experimental periods.

\begin{tabular}{ccccccccccc}
\hline \multirow{2}{*}{$\begin{array}{c}\text { Experimental } \\
\text { Felines }\end{array}$} & \multirow{2}{*}{ Group } & \multicolumn{7}{c}{ Titles obtained by RIFI/Experimental dates } \\
\cline { 3 - 10 } & & $-\mathbf{7}^{*}$ & $\mathbf{0}^{*}$ & $\mathbf{7}$ & $\mathbf{1 4}$ & $\mathbf{2 1}$ & $\mathbf{2 8}$ & $\mathbf{4 2}$ & $\mathbf{5 6}$ & $\mathbf{7 0}$ \\
\hline P1 & & - & - & - & - & $\cdot$ & 64 & 64 & 256 & 64 \\
P3 & Group I & - & - & - & - & - & 64 & 256 & 256 & 256 \\
P4 & "P") & - & - & - & 64 & 64 & 256 & 64 & 64 & 64 \\
Mean & & - & - & 64 & 64 & 64 & 256 & 256 & 256 & 256 \\
\hline Standard deviation & & & & 32.0 & 37.0 & 37.0 & 110.9 & 110.9 & 96.0 & 110.9 \\
\hline Kruskal-Wallis ${ }^{1}$ & & & & B & B & B & A & A & A & A \\
\hline RH1 & & - & - & - & 256 & 256 & 256 & 256 & ND & ND \\
RH2 & Group II & - & - & 64 & 256 & 256 & 256 & 256 & 256 & 64 \\
RH3 & (infected & - & - & - & 256 & 1024 & 1024 & 1024 & 1024 & 1024 \\
RH4 & "RH") & - & - & 64 & 256 & 256 & 256 & 256 & 256 & 64 \\
\hline Mean & & & & 32.0 & 256.0 & 448.0 & 448.0 & 448.0 & 512.0 & 384.0 \\
\hline Standard deviation & & & & 37.0 & 0.0 & 384.0 & 384.0 & 384.0 & 443.4 & 554.3 \\
\hline Kruskal-Wallis ${ }^{1}$ & & & & A & A & A & A & A & A & A \\
\hline C1 & & - & - & - & - & - & - & - & - & - \\
C2 & Group III & - & - & - & - & - & - & - & - & - \\
C3 & (control) & - & - & - & - & - & - & - & - & - \\
C4 & & - & - & - & - & - & - & - & - & - \\
\hline
\end{tabular}

*: Pre-inoculation period.

ND: not determined (feline excluded).

(-): Negative serology.

1: Values followed by the same letter, upper case in the column, do not differ from each other by the Kruskal-Wallis test ( $\mathrm{p} \geq 0.05$ ).

Parasitemia exerted by different T. gondii isolates on felines

Parasitemia by $T$. gondii was detected on five occasions in felines inoculated with tissue cysts (GI) and nine in those inoculated with tachyzoite (GII).
No statistical difference was observed $(\mathrm{p}>0.05)$ between the number diagnosed between groups of felines infected with the two $T$. gondii isolates (Table 2). 


\section{Discussion}

Felines infected with $T$. gondii tachyzoites belonging to $\mathrm{RH}$ strain (type I isolate) presented a higher number and variety of clinical signs than those infected with tissue cysts of $\mathrm{P}$ strain (type III isolate). Strains belonging to type I isolate are considered more virulent in mice when compared to those belonging to type II and III isolates, which present a more chronic behavior, being considered more cistogenic. Strains of type I isolate have a high capacity for replication and production of tachyzoites in the host organism, being their manifestations more evident in the acute phase of infection (SIBLEY et al., 1999; BARRAGAN; SIBLEY, 2002), which may explain why felines inoculated with this isolate manifested clinical signs in the first days after infection.

In the case of definitive hosts, there are few studies that correlate the occurrence of clinical signs during their infection with strains belonging to different genotypes (mainly I), in addition to the atypical or recombinant genotypes that have been diagnosed. In this sense, the results showed that type I isolate $\mathrm{RH}$ strain) of $T$. gondii was more virulent for domestic felines when compared to type III isolate (P strain), as previously observed in mice (SIBLEY et al., 1999; BARRAGAN; SIBLEY, 2002).

The most observed clinical signs in felines inoculated with $T$. gondii were apathy, hyporexia, bristled fur, and nasal and ocular secretion, most of them observed only in GII felines. Although clinical manifestations of toxoplasmosis are considered varied and common to several diseases, compromising organs and systems (CORRÊA; CORRÊA, 1992). Most clinical signs observed in the present study are common to toxoplasmic infection (DUBEY; LAPPIN, 2006).

Stress suffered by feline RH1 during urethral obstruction triggered the process of exacerbation of toxoplasmic infection, leading to the appearance of nervous symptoms in the animal. The increase of corticosteroids in the body under stress situations can cause the rupture of latent tissue cysts of $T$. gondii, causing the appearance of clinical symptoms (LAPPIN, 1999; DUBEY, 2006). Furthermore, clinical manifestations during toxoplasmosis are directly related to a deficiency in local or systemic immunity of the host organism, with immunologically incompetent individuals being more susceptible to primary or recurrent infections (SWINGER et al., 2009).

The nervous system is one of the main replication sites of $T$. gondii during infection(DUBEY; LAPPIN, 2006). Dubey and Carpenter (1993) confirmed the high tropism of this parasite by the nerve tissue of felines when diagnosing the presence of the agent in $96.4 \%$ of brains from 100 parasitized domestic felines. The appearance of neurological signs during toxoplasmic infection depends on the location of the parasite in the brain, cerebellum, or spinal cord, with protozoan replication in these tissues being the main cause of convulsive disorders, cranial nerve deficits, ataxia, tremors, paresis, and paralysis (DUBEY; LAPPIN, 2006). The high affinity of $T$. gondii for feline brains was a preponderant factor for the appearance of nervous symptomatology in feline RH1.

Feline RH1 was excluded from the study due to ethical and animal welfare reasons, with total remission of symptoms at the 63rd DAI, being subsequently orchidectomized and destined for donation.

The occurrence of soft feces in infected felines (P2, P4, and RH4) could not be correlated solely with toxoplasmic infection due to the lack of researches related to other agents causing this clinical sign. Despite diarrhea was diagnosed in only three felines in the present study, several authors reported its onset as one of the most frequently observed clinical signs in felines infected with $T$. gondii (CASTRO et al., 1976; DUBEY et al., 1995; NAVARRO et al., 1998; DUBEY; PROWELL, 2012).

Felids usually do not present clinical signs during the period of excretion of T. gondii oocysts, 
and episodes of short-term diarrhea are occasionally observed (LAPPIN, 2004). Among the three felines that presented soft feces, two are from the group inoculated with tissue cyst (GI), all episodes being diagnosed within the period that comprised the excretion of oocysts (5th to 13th DAI) by these animals, which may have contributed to the appearance of this clinical sign. Fecal consistency prevented sample collection and, consequently, the quantification of $T$. gondii oocysts excreted by felines $\mathrm{P} 2$ and $\mathrm{P} 4$ at these experimental dates.

Oocysts were investigated only in fecal samples collected from animals inoculated with tissue cysts of $T$. gondii (GI) since the infection due to their ingestion is considered the classic infection route for the studied animal species. The absence of coproparasitological analysis in fecal samples of felines inoculated via parenteral with tachyzoites (GII) occurred because oocyst formation and, consequently, its excretion in feces of cats inoculated by this route and using this parasitic stage rarely occur (JAMRA et al., 1985). Regarding group III, because these felines were proven to be negative for toxoplasmosis, with serological follow-up (IIF), the research on $T$. gondii oocysts in feces was also not performed.

Studies with oocysts in feces collected from felines inoculated with tissue cysts performed using light microscopy and bioassay techniques in mice have proven the excretion of these parasitic forms at different levels. Dubey (2005) inoculated orally T. gondii bradyzoites in felines and found that oocysts were eliminated from the feces of $100 \%$ of the animals, which was also observed in the present study, in which all cats belonging to group I eliminated oocysts after inoculation with tissue cysts of P strain (T. gondii isolate type III).

Bioassay in mice was more sensitive than the microscopy in the detection of oocysts in feline feces. Only the morphological characterization is not enough to identify this parasite in fecal samples of felines due to the similarity between oocysts from $T$. gondii and other protozoa found in feline feces (Hammondia hammondi and Besnoitia spp.) (DUBEY, 2009), making it necessary the association of the morphological characterization with the bioassay in mice or molecular biology techniques.

Felines infected with T. gondii strain AS-28 presented elimination of oocysts from the 3rd to 10th DAI (COSTA et al., 1979), differing from that observed in the present study, in which oocyst excretion by felines started only at the 5th DAI and lasted up to the 13th DAI. The period of oocyst elimination ( $T$. gondii) by felines is very variable and directly correlated with feline infection route, isolate of the parasite (strain), and its evolutionary stage at infection time (JAMRA et al., 1985; DUBEY, 1996, 2006).

According to Llorente Lacha et al. (1983) and Dubey and Prowell (2012), a feline can excrete more than 1 million oocysts daily during toxoplasmic infection, which was also evidenced in the present study, in which feline P3 eliminated 1,000,500 oocysts at the 9 th DAI.

All felines belonging to groups I and II were seroconverted (IgG titer anti- $T$. gondii $\geq 64)$ after inoculation, and a rapid seroconversion (IgG titer =64) was diagnosed in three felines (P4, RH2, and RH4) at seven days after inoculation, corroborating the data obtained from felines primo-infected with VPS strain, which also presented seroconversion at the 7th DAI (NAVARRO et al., 1998). In contrast, the maximum titer diagnosed in the present study was 1024 in feline RH3 from the 21st to the 70th DAI, differing from the data obtained by the same authors, who diagnosed a maximum titer of 16384 . These alterations may be attributed to differences inherent to inocula and animals used in the studies.

The statistical superiority $(\mathrm{p} \leq 0.05)$ of serological titers (IgG anti-T. gondii) obtained by felines inoculated with RH strain was notorious in relation to those obtained by inoculating $\mathrm{P}$ strain. The levels of antibodies diagnosed in felines after parasite inoculation evidenced a difference in the 
immunological profile between animals within each group. These particularly important fluctuations may be associated with the individual responsiveness of the used animals regulated by $\mathrm{H}-2$ histocompatibility complex antigen genes (SHARMA, 1990). This factor may explain the differences observed in the individual immunological responses of each experimental feline since animals were not genetically homogeneous.

Antibodies of IgG class are related to chronic toxoplasmosis, which can remain active for long periods (DUBEY, 1986). High activity of antibodies of $\operatorname{IgG}$ class was diagnosed until the last experimental date (70th DAI), mainly in felines inoculated with RH strain (T. gondii isolate I).

Parasitemia by $T$. gondii was evidenced in all inoculated felines (GI and GII) by the bioassay and mice, with no significant difference between groups of felines infected with different isolates. All occurrences of parasitemia were diagnosed between the 7th and 42nd DAI (nine), most of them (eight) observed until the 28th DAI. The highest occurrence of parasitemia in the first days after feline infection was possibly because this period is characterized by the acute phase of disease characterized by the presence of tachyzoites that can be found in the blood circulation of infected animals even under the action of the host immune system (DUBEY et al., 1970; LAPPIN et al., 1989b; SILVA; CHIOCCOLA, 2010).

Although all felines inoculated with isolate type I (RH strain) had manifested clinical infection during the experimental period, no deaths were evidenced during the accomplishment of this experiment unlike previous studies in mice inoculated with the same T. gondii isolate (MITSUKA et al., 1998).

\section{Conclusions}

Feline toxoplasmosis can manifest in both clinical and subclinical forms, with the appearance of clinical signs dependent on factors inherent to the parasite isolate, type of inoculum, and immunological condition of the host. Felines inoculated with tachyzoites of $T$. gondii isolate type I (RH strain) showed more clinical signs than those infected with type III isolates (P strain). Higher serological titers (IgG anti-T. gondii) and higher parasitemia by parasite were diagnosed in animals infected with isolate I.

\section{References}

BARRAGAN, A.; SIBLEY, L. D. Transepithelial migration of Toxoplasma gondii is linked to parasite motility and virulence. The Journal of Experimental Medicine, Birmingham, v. 195, n. 12, p. 1625-1633, 2002. DOI: $10.1084 /$ jem. 20020258

BERNSTEEN, L.; GREGORY, C. R.; ARONSON, L. R.; LIRTZMAN, R. A.; BRUMMER, D. G. Acute toxoplasmosis following renal transplantation in three cats and a dog. Journal of the American Veterinary Medical Association, New York, v. 215, n. 8, p. 11231126, 1999.

BRASIL. Ministério da Ciência, Tecnologia e Inovação, Conselho Nacional de Controle de Experimentação Animal (CONCEA), Portaria n. 596, de 25 de junho de 2013. Diretrizes da prática de eutanásia do Conselho Nacional de Controle de Experimentação Animal CONCEA, Brasília, 2013. Seção 1, p. 5.

CAMARGO, M. E. Improvided technique of indirect immunofluorescence for serological diagnosis of toxoplasmosis. Revista do Instituto de Medicina Tropical de São Paulo, São Paulo, v. 6, n. 3, p. 117-118, 1964.

CASTRO, G. A.; BADIAL-ACEVES, F.; SMITH, J. W.; DUDRICK, S. J.; WEISBRODT, N. W. Altered small bowel propulsion associated with parasitism. Gastroenterology, Bethesda, v. 71, n. 4, p. 620-625, 1976. DOI: $10.1016 / \mathrm{S} 0016-5085(76) 80553-7$

CORRÊA, W. M.; CORRÊA, C. N. M. Toxoplasmose. Enfermidades infecciosas dos mamíferos domésticos. Rio de Janeiro: Medsi, 1992. 757 p.

COSTA, A. J.; ARAUJO, F. G.; COSTA, J. O.; LIMA, J. D.; NASCIMENTO, E. Experimental infection of bovines with oocysts of Toxoplasma gondii. Journal of Parasitology, Laurence, v. 63, n. 2, p. 212-218, 1977. DOI: $10.2307 / 3280042$

COSTA, A. J.; COSTA, J. O.; LIMA, J. D.; ARAÚJO, F. G. Produção de oocistos de Toxoplasma gondii em gatos experimentalmente infectados. Ciência e Cultura, São Paulo, v. 31, n. 16, p. 1170, 1979. 
DUBEY, J. P. Comparative infectivity of oocysts and bradyzoites of Toxoplasma gondii for intermediate (mice) and definitive (cats) hosts. Veterinary Parasitology, Amsterdam, v. 140, n. 1-2, p. 69-75, 2006. DOI: 10.1016/j.vetpar.2006.03.018

DUBEY, J. P. History of the discovery of the life cycle of Toxoplasma gondii. International Journal for Parasitology, Oxford, v. 39, n. 8, p. 877-882, 2009. DOI: 10.1016/j.jpara.2009.01.005

DUBEY, J. P. Infectivity and pathogenicity of Toxoplasma gondii oocysts for cats. Journal of Parasitology, Laurence, v. 82 , n. 6 , p. $957-960$, 1996. DOI: $10.2307 / 3284206$

DUBEY, J. P. Toxoplasmosis. Journal of the American Veterinary Medical Association, New York, v. 189, n. 2, p. 166-170, 1986.

DUBEY, J. P. Unexpected oocyst shedding by cats fed Toxoplasma gondii tachyzoites: in vivo stage conversion and strain variation. Toxoplasmosis-a waterborne zoonosis. Veterinary Parasitology, Amsterdam, v. 133, n. 4, p. 289-298, 2005. DOI: 10.1016/j.vetpar.2005.06.007

DUBEY, J. P.; CARPENTER, J. L. Histologically confirmed clinical toxoplasmosis in cats: 100 cases (19521990). Journal of the American Hospital Association, Lakewood, v. 203, n. 11, p. 1556-1566, 1993.

DUBEY, J. P.; LAPPIN, M. R. Toxoplasmosis and neosporosis. In: GREENE, C. E. Infectious diseases of the dog and cat. $3^{\text {th }}$ ed. St. Louis: Elsevier, 2006. p. 754775 .

DUBEY, J. P.; LAPPIN, M. R.; THULLIEZ, M. Diagnosis of induced toxoplasmosis in neonatal cats. Journal of the American Veterinary Medical Association, New York, v. 207, n. 2, p. 179-185, 1995.

DUBEY, J. P.; LINDSAY, D. S.; SPEER, C. A. Structures of Toxoplasma gondii tachyzoites, bradyzoites, and sporozoites and biology and development of tissue cysts. Clinical Microbiology Reviews, Washington, v. 11, n. 2, p. 267-299, 1998.

DUBEY, J. P.; MILLER, N. L.; FRENKEL, J. K. The Toxoplasma gondii oocyst from cat feces. Journal of Experimental Medicine, Birmingham, v. 132, n. 4, p. 636-662, 1970. DOI: 10.1084/jem.132.4.636.

DUBEY, J. P.; PROWELL, M. Ante-mortem diagnosis diarrhea, oocyst shedding, treatment, isolation and genetic typing of Toxoplasma gondii associated with clinical toxoplasmosis in a naturally infected cat. Journal of Parasitology, Laurence, v. 5, n. 58, p. 158-160, 2012. DOI: $10.1645 / \mathrm{GE}-3257.1$

DUBEY, J. P.; SWAN, G. V.; FRENKEL, J. K. A simplified method for isolation of Toxoplasma gondii from the faeces of cats. Journal of Parasitology, Laurence, v. 58, n. 5, p. 1005-1006, 1972. DOI: 10.2307/3286603

FEITOSA, F. L. F. Semiologia veterinária: a arte do diagnóstico. 2. ed. São Paulo: Editora Roca, 2008. 735p.

FERGUSON, D. J. P. Identification of faecal transmission of Toxoplasma gondii: Small science, large characters. International Journal for Parasitology, Oxford, v. 39, n. 8, p. 871-875, 2009. DOI: 10.1016/j.ijpara.2009.01.003

JAMRA, L. M. F.; SOGORB, S. F.; GUIMARÃES, E. C. Reinfecção pelo Toxoplasma gondii Nicolle \& Manceaux, 1909 em camundongos e gatos. Revista do Instituto de Medicina Tropical de São Paulo, São Paulo, v. 27 , n. 6 , p. $318-327,1985$. DOI: 10.1590/S003646651985000600005

LAPPIN, M. R. Feline toxoplasmosis. In Practice, London, v. 21 , n. 10 , p. 578-589, 1999. DOI: $10.1136 /$ inpract.21.10.578

LAPPIN, M. R. Segredo em medicina interna de felinos. Porto Alegre: Artmed, 2004. 506 p.

LAPPIN, M. R.; GREENE, C. E.; PRESTWOOD, A. K.; DAWE, D. L.; TARLETON, R. L. Diagnosis of recent Toxoplasma gondii infection in cats by use of an enzymelinked immunosorbent assay for immunoglobulin. American Journal of Veterinary Research, Chicago, v. 50, n. 9, p. 1580-1585, 1989a.

LAPPIN, M. R.; LAPPIN, M. R.; GREENE, C. E.; WINSTON, S.; TOLL, S. L.; EPSTEIN, M. E. Clinical feline toxoplasmosis serologic diagnosis and therapeutic management of 15 cases. Journal of Veterinary Internal Medicine, Greenwood Village, v. 3, n. 3, p. 3139-143, 1989b. DOI: 10.1111/j.1939-1676.1989.tb03089.x

LLORENTE LACHA, V.; MARTINEZ FERNANDEZ, A. R.; GARCIA DIAZ, J. J. Caracterizacion de 1 cepa V-1 de Toxoplasma gondii (Sporozoa). II. Inoculacion en hospedadores definitivos. Revista Ibérica de Parasitologia, Granada, v. 43, n. 1, p. 15-24, 1983.

MITSUKA, R.; BECKNER da SILVA, A. C.; NAVARRO, I. T.; BREGANÓ, J. W.; VIDOTTO, O. Toxoplasma gondii: I. Avaliação da virulência de oito amostras. Brazilian Journal of Veterinary Research and Animal Science, São Paulo, v. 35, n. 1, p. 29-31, 1998. DOI: $10.1590 / \mathrm{S} 1413-95961998000100005$

NAVARRO, I. T.; VIDOTTO, O.; SILVA, A. C. B.; MITSUKA, R.; JANKEVICIUS, J. V.; SHIDA, P. N.; CORTÊS, J. A. Comportamento imunológico e antigênico de cinco amostras de Toxoplasma gondii inoculadas em gatos. Ciência Rural, Santa Maria, v. 28, n. 3, p. 453-459, 1998. DOI: 10.1590/S0103-84781998000300017

PENA, H. F. J.; GENNARI, S. M.; DUBEY, J. P.; SU, C. 
Population structure and mouse-virulence of Toxoplasma gondii in Brazil. International Journal for Parasitology, Oxford, v. 38, n. 5, p. 561-569, 2008. DOI: 10.1016/j. ijpara.2007.09.004

REY, L. Bases da parasitologia médica. Rio de Janeiro: Guanabara Koogan, 2002. 379 p.

SABIN, A. B. Toxoplasmic encephalites in children. Journal of the American Medical Association, Cidade, v. 116, n. 9, p. 801-807, 1941. DOI: 10.1001/ jama.1941.02820090001001

SAKAMOTO, C. A. M.; GENNARI, S. M.; PENA, H. F.; TONIOLLO, G. H.; LOPES, W. D.; BICHUETTE, M. A.; BETINI, C. M.; AMARANTE, A. F.; BRESCIANI, K. D. Experimental infection of pregnant queens with two major Brazilian clonal lineages of Toxoplasma gondii. Parasitology Research, Berlin, v. 105, n. 5, p. 1311-1316, 2009. DOI: 10.1007/s00436-009-1558-y

SHARMA, S. D. Immunology of toxoplasmosis. In: WYLER, D. J. Modern parasite biology cellular, immunological and molecular aspects. New York: W. H. Freeman \& Co, 1990. p. 157-183.

SIBLEY, L. D.; MORDUE, D.; HOWE, D. K. Experimental approaches to understanding virulence in toxoplasmosis. Immunobiology, v. 201, n. 2, p. 210-224, 1999. DOI: $10.1016 / \mathrm{S} 0171-2985(99) 80061-8$
SILVA, T. A. C.; CHIOCCOLA, V. L. P. Fase aguda da infecção por Toxoplasma gondii: avaliação do parasitismo sanguíneo e resposta humoral em camundongos isogênicos. Scientia Medica, Porto Alegre, v. 20, n. 1, p. 88-92, 2010.

STATISTICAL ANALYSIS SYSTEM INSTITUTE SAS Institute. SAS User's Guide: Estatistics. Cary: SAS Institute, Inc., 2001.

SULLIVAN, W. J.; JEFFERS, V. Mechanisms of Toxoplasma gondii persistence and latency. FEMS Microbiology Reviews, Oxford, v. 36, n. 3, p. 717-733, 2012. DOI: 10.1111/j.1574-6976.2011.00305.x

SWINGER, R. L.; SHMIDT, K. A.; DUBIELZIG, R. R. Keratoconjunctivitis associated with Toxoplasma gondii in a dog. Veterinary Ophthalmology, Meridian, v. 12, n. 1, p. 56-60, 2009. DOI: 10.1111/j.1463-5224.2009.00675.x

ZAMAN, V. Morfology of Toxoplasma oocysts and its comparison with other cat coccidia. South Asian Journal Tropical Medicine Public Health, Bangkok, v. 1, n. 3, p. 329-335, 1970. 
